\title{
LITHUANIAN \\ ENERGY SECURITY
}

\section{ANNUAL REVIEW \\ 2011-2012}

VYTAUTAS MAGNUS UNIVERSITY

LITHUANIAN ENERGY INSTITUTE

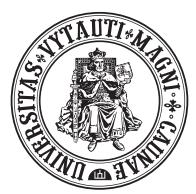

KAUNAS, 2013 
UDK 621.311(474.5)

\section{The Editorial Board}

Head of the Energy Security Research Centre - Prof. Dr. Hab. Juozas Augutis Centre senior researcher - Prof. Dr. Ričardas Krikštolaitis Centre researcher - Assoc. Prof. Dr. Dainius Genys

Centre junior researcher - PhD candidate Giedrius Česnakas

Centre junior co-researcher - Mg. Agnė Čepinskytė

\section{Contacts of the Energy Security Research Centre}

Address: K. Donelaičio g. 58, LT-44248, Kaunas

Web page: www.estc.lt

Telephone number of the head of the Centre: +370 37203775

Telephone number of the Centre: (8 37) 327933

E-mail of the head of the Centre: j.augutis@if.vdu.lt

E-mails of coordinators of the Centre: r.krikstolaitis@if.vdu.lt;

g.cesnakas@pmdf.vdu.lt;

d.genys@smf.vdu.lt

This research was funded by a Grant (No. ATE-06/2012)

from the Research Council of Lithuania.

ISSN 2335-7029

e-ISSN 2335-7045

(C) Vytautas Magnus University, 2013

(C) Lithuanian Energy Institute, 2013 


\section{CONTENTS}

Foreword by the head of Energy Security Research Centre ... . 4 The sources of threats to Lithuanian energy security. . . . . . 7 Assessment of energy security level . . . . . . . . . . . 10

Lithuanian energy security level 2007-2011 . . . . . . . . . 13

Impact of the implementation of the biggest energy projects on Lithuanian energy security . . . . . . . . 16 


\section{FOREWORD BY THE HEAD OF ENERGY SECURITY RESEARCH CENTRE}

Since the early days of the newly independent Lithuania, energy security and energy independence have been the top priority issues. Lithuanian road of independence started with Russian energy blockade, eventual cut off of Russian oil supplies through „Druzhba II“ pipeline and rising gas prices. Lithuania was compelled to shut down Ignalina $\mathrm{Nu}$ clear Power Plant as one of the conditions of its accession to the European Union. Moreover, pursuant to continuously stricter environmental protection requirements the majority of Lithuanian thermoelectric power stations may have to be closed down due to too high emissions. Record level prices of imported gas, huge electricity import from Russia and other countries, enormous bills for the heating of unrenovated and uneconomical housing sector cause social tensions, grievances and disappointment.

At first glance it would seem that solution of the issues is a technical and economic one. It would seem that to resolve the problems it is sufficient to merely prepare projects of energy system's development and to find funding for their implementation. However, it is not as simple. The first National Energy Strategy was adopted already in 1994 and was followed by four new strategies (the latest one - in 2012), a plenty of amendments, implementation plans and other documents. All the energy strategies and their implementation plans foresaw technical projects, necessary equipment, organisational means etc. Evaluation based on economic calculations has shown that the proposed scenarios of energy system's development are effective. They would allow reducing energy prices and energy consumption, as well as partially decreasing dependency on energy import. Nevertheless, the projects have remained virtually unimplemented. Social mistrust in suggested solutions has grown, renovation of housing has not started 
and independent energy producers who propose using biomass have been struggling. Moreover, in the referendum (2012) the society voted against the construction of Visaginas Nuclear Power Plant. The Liquefied Natural Gas Terminal has as well been criticised.

From the very beginning, energy projects have been based on the arguments of ensuring energy security and energy independence. The most recent National Energy Strategy was even titled the National Energy Independence Strategy. Nonetheless, in the majority of documents the definition of energy security has been approached rather narrowly. It usually encompasses diversification of energy sources and fuel supplies, connection of national energy networks to the Western European networks and increase of domestic energy production capabilities. However, while deciding on energy development plans and assessing energy security, it is also crucial to take into account geopolitical and socio-political factors. The main task of energy security analysis is to evaluate the resistance of existing or planned energy system against various threats (technological, natural, economic, geopolitical and socio-political). These threats, if materialised, could result into disruptions or even severance of energy and fuel supplies to consumers, as well as rise of energy prices. Socio-political and geopolitical threats can potentially obstruct or even devastate implementation of energy projects. Failing to take such factors into account, the plans will only remain plans and will not bring any energy independence, lower energy prices, or sustainable development of energy sector.

The task of energy security research is twofold. First, it is to ascertain all the factors that affect energy security, to determine their interdependent relationship and to create models capable of showing the impact that different impediments will have on Lithuanian energy system. In addition, it is important to establish what is the likelihood of the occurrence of such impediments and what means are available to neutralise their consequences. Once these objectives are achieved, the second part of the task can be carried out. That is, it is then possible to assess the level of national energy security, to show how various projects will affect it and to compare Lithuanian energy security with energy security of other countries. 
Having generalised the long-term experience in the field of energy security assessment, in the present publication we provide the results of several studies. We hope that this publication will become the annual report of the Energy Security Research Centre and will allow seeing the change in Lithuanian energy security over time, determining certain trends in the change, as well as highlighting the most important factors that one should pay the biggest attention to. 


\section{THE SOURCES OF THREATS TO LITHUANIAN ENERGY SECURITY}

Every energy system is surrounded by a variety of threats. A threat could be defined as any potential danger that exists within or outside the energy system and that has a potential to result into some kind of obstruction of that system. The origins of threats are various. They depend on the country where the energy system exists, its geographic and political region/context. Threats can roughly be divided into several groups.

The best known and the most common threats are natural disasters: earthquakes, tsunamis, floods, tornados, storms, blizzards, frosts, draughts etc. These threats depend on the local seismic, climate and other geographic conditions.

Other threats are caused by the infrastructure and reliability of the energy system itself. These are different accidents and damages that occur due to technical reasons and may cause serious disruptions of the energy system or even a complete cut off of energy supplies.

Energy security depends on the stability of prices of energy and fuel. Therefore, economic crises, isolation of the system, as well as domination of a particular source of fuel, producer or supplier constitute the third group of threats.

The fourth group of threats belongs to socio-political and geopolitical area. These threats have been discussed extensively in literature. In spite of that, it is still difficult to define them and there are hardly any quantitative measures to evaluate the probability of the occurrence of such threats. The existence (or imagined existence) of these threats has a substantial impact on decision-making with regard to energy development projects. There are almost no state in the world that is energy independent and that is able to provide itself with energy resources without having to import any. Almost all states face energy 
dependency. This causes a lot of tensions in international relations. Thus, these threats, albeit being not as evident as natural disasters or technical accidents, are significant and have serious consequences. Threat of terrorism also belongs to socio-political threats.

Lithuania is not an energy rich country. It is not fully integrated in the free energy and fuel markets and is highly dependent on a small number of states that are the main energy suppliers. The existing Lithuanian systems of energy production, supply and distribution are not enough modernised. Therefore, virtually all kinds of threats are relevant to the Lithuanian energy system. Lithuania is not in an active seismic zone, the chances of tornados are small. However, there are other natural adverse events that can and do cause accidents in energy systems: cyclones, storms, hurricanes etc. Over the last decade, the likelihood of the occurrence of such natural events has grown. Every year, winds cut off electricity supplies for a shorter or a longer period of time and hinder the traffic. The dangerousness of such events increases during winter due to snow, icing etc. Fairly significant threats arise as a result of floods, ice hummocks and heavy showers. Moreover, a big part of the infrastructure of energy system is in woodlands. Therefore, there is a threat of wildfire. Such natural events as lightning, draught, fog and similar can also be perceived as natural threats that can cause impediments in energy production, transmission and distribution, as well as in fuel preparation, transportation and preservation processes.

Threats caused by the infrastructure reliability issues of energy sector are unlikely to materialise in Lithuania. Equipment in electricity, gas, heat and other sectors is not new and the recent investment in it was little. However, due to the fact that the equipment for generation, transmission and distribution of energy was planned for much bigger loading capacities than they are at the moment, there are considerable excess capabilities and qualified personnel. This allows preventing bigger accidents in Lithuanian energy systems. Nevertheless, technical threats remain and the minimisation of their consequences demands constant investment. In addition, it is necessary to renew equipment and technologies, which can only be done after extensive scientific research. 
Being dependent on the single gas supplier and electricity import from the sole country, Lithuania is in great risk. Lithuania is highly affected by high fuel and energy prices when compared to other member states of the European Union. Abuse of dominance by monopolies is a contributing factor to the rising prices. Unsteady development of the global economy, political instability in a state and economic crises, as well as an overly rapid development of the economics of particular regions destabilise consumption of resources and their prices. Debts and slow economic development of a state limit the ability to react to rapid changes in the prices of energy resources. It also makes it more difficult to ensure steady supplies and to implement necessary energy projects.

Big energy projects often attract the interest of various business and political groups. This can cause economic and political conflicts, and eventually form a negative view in society. The clash between governmental and energy experts over energy system's priorities and the principles of their implementation, hinder Government's communication with society. Therefore, it becomes difficult to efficiently inform and convince the society about the adequacy and effectiveness of existing projects.

High level of corruption allows certain groups consolidating their interests. As a result, representation of public interests decreases. Energy politics become no longer focused on ensuring the effectiveness, economy and security. Instead, it starts serving short-term interests of a small group and this is done using state resources. 


\section{ASSESSMENT OF ENERGY SECURITY LEVEL}

Energy security of a state depends on many factors. These factors have different impact, they change over time and are often inter-dependent. In order to assess all the conditions and circumstances that have an impact on energy security level, the present methodology uses energy security indicators. They allow assessing different circumstances, factors, conditions and components that cover all the areas of energy security. Having analysed various criteria, energy security indicators are combined into one integral characteristic - the so-called energy security level. Using the same methodology it is possible to compare energy security level of different energy strategies as well as different states and to assess the impact that various projects will have on the energy security level.

There were three blocks of indicators used in assessing Lithuanian energy security: technical, economic and socio-political. Two of these blocks (technical and economic) were determined on the basis of the kind of fuel that is used in energy system. In addition, electricity and heat were included into the block as separate indicator groups. All the blocks were given the same weight, assuming that they affect energy security level equally.

In creating indicators of the technical block, attention was paid to technical and reliability factors emphasising the capacity of fuel supply to Lithuania, annual or maximal needs, remaining resources of energy generation and accumulated fuel reserves.

In designing indicators of economic block, attention was given the ability to freely choose suppliers of the specific kind of fuel, the diversification of fuel suppliers and the relation between imported fuel and its annual consumption. 
In creating indicators of socio-political block, two groups of indicators were distinguished: geopolitical indicators and socio-political indicators. The aim of geopolitical indicators is to evaluate globally published political ratings of the State in question, as well as the other States which supply energy resources, serve as transit countries for the energy supplies or own property in energy enterprises in the State in question. The aim of socio-political indicators is to assess how a State complies with its international obligations, how it implements EU directives and programmes of effective energy consumption, as well as to find out the public opinion on the existing projects.

Specific weight was given to each of the indicators in the group, to each of the indicators' group in the block and to each of the blocks themselves. All the weights were calculated relying on statistical data or expert assessment methods. All in all, 68 different indicators are used in the research. The overall energy security level is determined by using calculation methods created by the authors of the study.

Three conditions of (in)security can be distinguished in energy security research - critical, pre-critical and normal.

- Critical condition is when energy security level is below 33\%. This means that security level is unacceptable and actions must be taken to eliminate the causes of such condition, because it is a threat to energy security.

- Pre-critical condition is when energy security level is between $33 \%$ and $66 \%$. This means that security level is tolerable, however, it is likely that threats to security might emerge. In due time, appropriate actions should be undertaken in order to change this condition to an acceptable one.

- Normal condition is when energy security level is above $66 \%$. This means that security level is acceptable, security is ensured. In this case actions should only be aimed at maintaining the present level of security.

The meanings of different indicators have been established relying on statistical and technical data, economic modelling, reliability analysis and expert evaluation. 
The data of indicators is acquired relying on statistical data, economic modelling, reliability analysis and expert assessment. The value of each indicator used in the study was included into the security level assessment system. Further, factual values of indicators were normalised (so they can be compared) and threshold values were determined based on which different conditions are distinguished. Indicators were then evaluated in the scales of condition assessment. Finally, the values of all the indicators were brought together and the overall security level was assessed.

Threshold values of the indicators are determined relying on technical regulations, normative documents of the exploitation of equipment and expert assessment. In establishing indicator's condition, the positive direction of the indicator is as well important. It can be ascending or descending. In the former case the higher meaning of an indicator corresponds to the higher security level, while in the latter case corresponds to the lower security level. 


\section{LITHUANIAN ENERGY SECURITY LEVEL 2007-2011}

Lithuanian energy security has been assessed since 2007. 2007 are chosen as the base year. No significant changes in the Lithuanian energy system happened that year. In 2007 Lithuanian energy security level was $52.8 \%$ out of the maximum of $100 \%$. Over the last five years, the highest security level was reached in 2008 (54.1\%), and the lowest security level - in 2010 (51.2\%) which was immediately after the closure of Ignalina Nuclear Power Plant.

Dynamics of the energy security level are shown in the Table 1 and Picture 1. After the closure of Ignalina Nuclear Power Plant in 2010, the situation in energy sector has changed due to the change of the dominant source of electricity generation. After the closure, generation of base load electricity generation has been taken over by the gas consuming power plants. The gas supply is the most sensitive to economic and geopolitical factors. Therefore, domination of this type of fuel in energy production decreases energy security.

The slight increase in the energy security level in 2011 is related to the emergence of electricity market and the accretion of the part of biomass-biofuel in the energy production. The import of more electricity as a result of the closure of Ignalina Nuclear Power Plant affects the energy security negatively, although the situation is softened by the fact that purchasing electricity in the market is cheaper than producing it in Lithuania. Following the liberalisation of electricity market, a majority of consumers have had the opportunity to choose the producer or to buy electricity in the market. This has as well added to the improvement of security level. As the overall energy security level is assessed by adding up all the indicators, a worse situation in one energy sector is partially compensated by a better situation in another sector. However, the indicators in the critical condition show that 
there are fundamental problems in the energy system and they must be fixed. Table 2 provides the distribution of all 68 indicators among the three conditions every year. More than one third of all indicators are in the critical condition. That makes a significant negative impact on the overall energy security level.

Table 1. Energy security level dynamics 2007-2011

\begin{tabular}{|l|c|c|c|c|c|}
\hline Year & $\mathbf{2 0 0 7}$ & $\mathbf{2 0 0 8}$ & $\mathbf{2 0 0 9}$ & $\mathbf{2 0 1 0}$ & $\mathbf{2 0 1 1}$ \\
\hline Energy security level & $52.8 \%$ & $54.1 \%$ & $53.9 \%$ & $51.2 \%$ & $51.5 \%$ \\
\hline
\end{tabular}

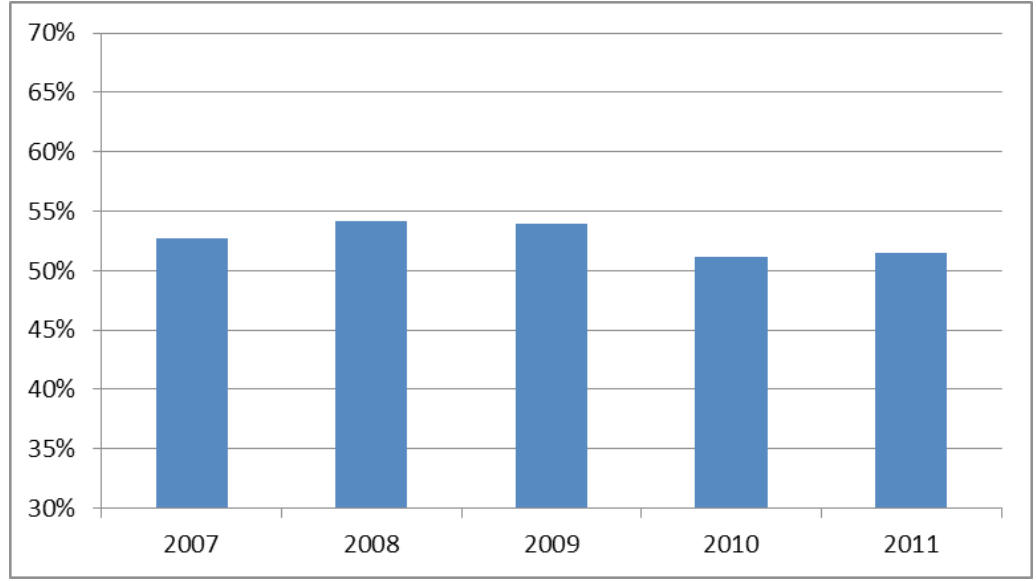

Picture 1. Energy security dynamics 2007-2011

Table 2. Distribution of indicators among different conditions

\begin{tabular}{|l|c|c|c|c|c|}
\hline Year & $\mathbf{2 0 0 7}$ & $\mathbf{2 0 0 8}$ & $\mathbf{2 0 0 9}$ & $\mathbf{2 0 1 0}$ & $\mathbf{2 0 1 1}$ \\
\hline Critical condition & 23 & 22 & 22 & 25 & 24 \\
\hline Pre-critical condition & 22 & 24 & 25 & 22 & 23 \\
\hline Normal condition & 23 & 22 & 21 & 21 & 21 \\
\hline
\end{tabular}

Most of the indicators that fall under the zone of the critical condition belong to the gas sector: relation between the gas purchase cost in Lithuania and the average gas purchase cost in the EU countries; 
the portion of gas that is purchased from the main supplier; excess dependence of energy production from gas. A good amount of indicators in the critical zone are there due to undeveloped market conditions, especially in the heat production sector. In the block of socio-political indicators, high Lithuanian dependency on one State and disproportionally big expenses per one individual on energy (as compared to the average income) make the most significant negative impact. 


\section{IMPACT OF THE IMPLEMENTATION OF THE BIGGEST ENERGY PROJECTS ON LITHUANIAN ENERGY SECURITY}

Table 3. The most significant energy projects

\begin{tabular}{|c|c|c|c|c|}
\hline Project & $\begin{array}{l}\text { Aim of the } \\
\text { project }\end{array}$ & $\begin{array}{l}\text { Period of } \\
\text { implementation }\end{array}$ & $\begin{array}{l}\text { Expenditure } \\
\text { of the project }\end{array}$ & $\begin{array}{l}\text { Feasibility of } \\
\text { the project }\end{array}$ \\
\hline $\begin{array}{l}\text { "Nord Balt" } \\
\text { electricity } \\
\text { connection }\end{array}$ & $\begin{array}{l}\text { To connect } \\
\text { Lithuanian and } \\
\text { Swedish elec- } \\
\text { tricity transmis- } \\
\text { sion systems via } \\
700 \text { MW con- } \\
\text { nection link. }\end{array}$ & $\begin{array}{l}\text { The project is } \\
\text { foreseen to be } \\
\text { completed by } \\
2016 .\end{array}$ & $\begin{array}{l}1.9 \text { billion } \\
\text { LTL. Agreed } \\
\text { Lithuanian } \\
\text { investment will } \\
\text { reach } 479.7 \\
\text { million LTL. }\end{array}$ & $\begin{array}{l}\text { The project is } \\
\text { feasible. }\end{array}$ \\
\hline $\begin{array}{l}\text { "LitPolLink" } \\
\text { electricity } \\
\text { connection }\end{array}$ & $\begin{array}{l}\text { To connect } \\
\text { Lithuanian } \\
\text { electricity } \\
\text { transmission } \\
\text { system to the } \\
\text { electricity } \\
\text { network system } \\
\text { of continental } \\
\text { Europe via } \\
500 \text { MW power } \\
\text { connection link. }\end{array}$ & $\begin{array}{l}\text { The beginning of } \\
\text { exploitation of the } \\
\text { connection link is } \\
\text { foreseen in } 2015 \text {. } \\
1000 \text { MW link } \\
\text { is planned to be } \\
\text { exploited starting } \\
\text { in } 2020 \text {. }\end{array}$ & $\begin{array}{l}1.28 \text { billion } \\
\text { LTL. } \\
\text { Lithuanian } \\
\text { share of } \\
\text { investment is } \\
\text { approximately } \\
60 \text { million } \\
\text { LTL. }\end{array}$ & $\begin{array}{l}\text { The project is } \\
\text { feasible. }\end{array}$ \\
\hline $\begin{array}{l}\text { Liquefied } \\
\text { natural gas } \\
\text { terminal }\end{array}$ & $\begin{array}{l}\text { To create } \\
\text { alternatives to } \\
\text { the natural gas } \\
\text { import from } \\
\text { Russia, around } \\
3 \text { billion } \mathrm{m}^{3} \text { per } \\
\text { year. }\end{array}$ & $\begin{array}{l}\text { The beginning of } \\
\text { terminal's opera- } \\
\text { tion is foreseen in } \\
2014 .\end{array}$ & $\begin{array}{l}\text { Until the start } \\
\text { of operations } \\
\text { by LNG } \\
\text { terminal, the } \\
\text { demand of } \\
\text { investment is } \\
\text { approximately } \\
604 \text { million } \\
\text { LTL. The } \\
\text { final cost of } \\
\text { the project is } \\
\text { approximately } \\
1.2 \text { billion LTL. }\end{array}$ & $\begin{array}{l}\text { The project is } \\
\text { feasible. }\end{array}$ \\
\hline
\end{tabular}




\begin{tabular}{|c|c|c|c|c|}
\hline Project & $\begin{array}{l}\text { Aim of the } \\
\text { project }\end{array}$ & $\begin{array}{l}\text { Period of } \\
\text { implementation }\end{array}$ & $\begin{array}{l}\text { Expenditure } \\
\text { of the project }\end{array}$ & $\begin{array}{l}\text { Feasibility of } \\
\text { the project }\end{array}$ \\
\hline $\begin{array}{l}\text { Visaginas } \\
\text { Nuclear } \\
\text { Power Plant }\end{array}$ & $\begin{array}{l}\text { It is foreseen } \\
\text { to build an } \\
\text { advanced } \\
\text { reactor of } \\
\text { boiling water } \\
\text { ABWR (power } \\
\text { of } 1350 \mathrm{MW} \text { ). } \\
\text { Lithuania } \\
\text { will receive } \\
\text { approximately } \\
500 \text { MW. }\end{array}$ & $\begin{array}{l}\text { The planned } \\
\text { beginning of NPP } \\
\text { exploitation is } \\
\text { foreseen in } 2020- \\
2022 \text {. }\end{array}$ & $\begin{array}{l}17 \text { billion LTL. } \\
\text { Lithuanian } \\
\text { share of } \\
\text { investment is } \\
6.5 \text { billion LTL. }\end{array}$ & $\begin{array}{l}\text { The } \\
\text { likelihood of } \\
\text { completion of } \\
\text { the project is } \\
\text { small. }\end{array}$ \\
\hline $\begin{array}{l}\text { Projects } \\
\text { concerning } \\
\text { the } \\
\text { production } \\
\text { of local and } \\
\text { renewable } \\
\text { energy } \\
\text { resources }\end{array}$ & $\begin{array}{l}\text { To increase the } \\
\text { use of local and } \\
\text { renewable ener- } \\
\text { gy resources for } \\
\text { electricity and } \\
\text { heat produc- } \\
\text { tion. By } 2020 \\
\text { it is planned } \\
\text { to install wind } \\
\text { power plants of } \\
500 \text { MW gross } \\
\text { power, biomass } \\
\text { based power } \\
\text { plants of at } \\
\text { least } 355 \text { MW } \\
\text { power, hydro } \\
\text { power plants } \\
\text { of } 141 \text { MW } \\
\text { power and solar } \\
\text { power plants of } \\
10 \text { MW. }\end{array}$ & $\begin{array}{l}\text { By } 2020, \text { RES } \\
\text { should constitute } \\
\text { not less than } 23 \\
\text { per cent of the } \\
\text { overall energy } \\
\text { consumption } \\
\text { (not less than } 20 \\
\text { per cent in the } \\
\text { electricity sector } \\
\text { and not less than } \\
60 \text { per cent in the } \\
\text { heat sector). }\end{array}$ & $\begin{array}{l}\text { Necessary } \\
\text { investment } \\
\text { reaches } 3.2- \\
4.2 \text { billion LTL } \\
\text { (mostly private } \\
\text { investment). } \\
\text { Wind and solar } \\
\text { energy is subsi- } \\
\text { dised. }\end{array}$ & $\begin{array}{l}\text { RES projects } \\
\text { are feasible. }\end{array}$ \\
\hline
\end{tabular}

Based on the existing energy projects that are supposed to increase Lithuanian energy security level, five security scenarios have been modelled and calculated. These scenarios show what impact on Lithuanian energy security level each of the projects will have both separately and combined together. The projects are the following: renewable energy resources development (RES), "NordBalt” connection, LNG terminal 
(LNGT), "LitPolLink" connection and Visaginas NPP (VNPP). In the modelling of scenarios, the results were calculated independently from the fact of when and if the projects will be implemented.

The results show that Lithuanian energy security level would increase the most (as compared to the level in 2011) in the case of the completion of LNGT project. LNG terminal would increase the security level by $5.8 \%$. If the project was implemented successfully Lithuanian energy security level would reach $57.3 \%$ in comparison to the level in 2011. RES and VNPP projects would increase the energy security level roughly equally - more than by 3\% each. Energy security level as compared to 2011 would as well increase in the cases of successful implementation of the "NordBalt" and "LitPolLink" projects.

Table 4. Energy security level change in per cents as compared to 2011 level

\begin{tabular}{|l|c|c|c|c|c|}
\hline \multirow{2}{*}{} & \multicolumn{5}{|c|}{ Scenarios } \\
\cline { 2 - 6 } & RES & "NordBalt" & LNGT & "LitPolLink" & VNPP \\
\hline Energy security level & $3.4 \%$ & $1.8 \%$ & $5.8 \%$ & $1.5 \%$ & $3.1 \%$ \\
\hline
\end{tabular}

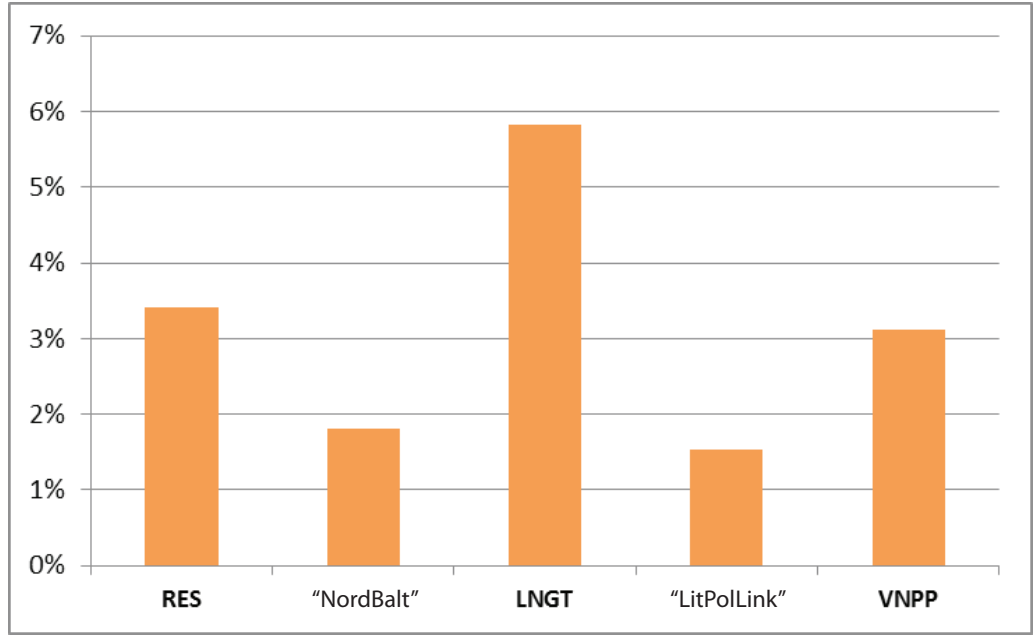

Picture 2. Energy security level change in per cents as compared to 2011 level 


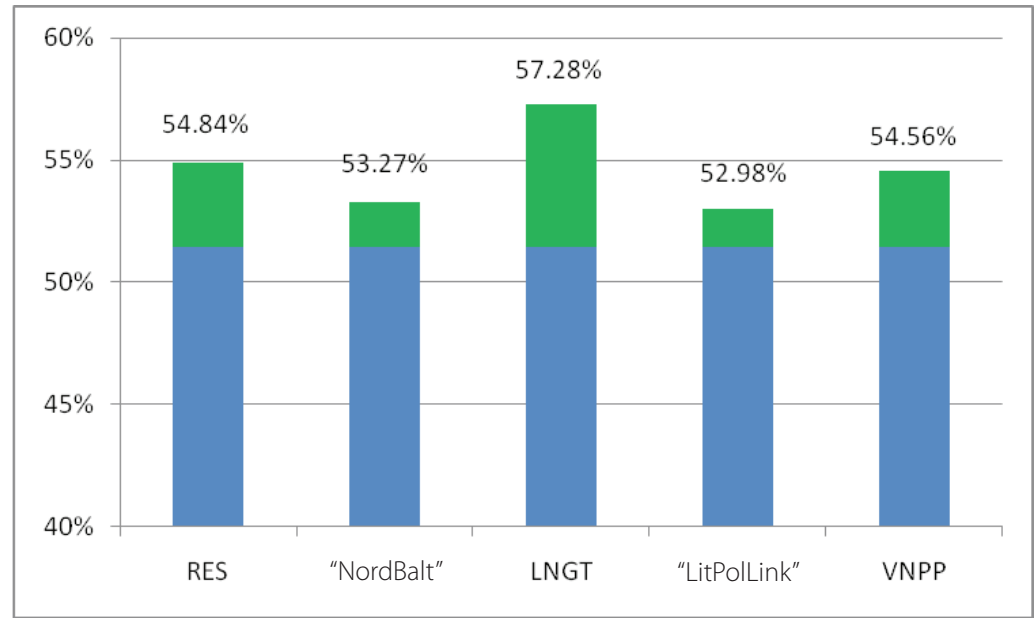

Picture 3. Energy security level in case of completion of the separate projects (as compared to 2011 level)

Pictures 2 and 3 show the potential Lithuanian security level (as compared to the level in 2011) if each of the projects is completed. The blue zone of the column diagram marks Lithuanian energy security level in 2011 . The green zone marks the potential energy security level.

If all of the above discussed energy projects were implemented Lithuanian energy security level would increase rather significantly. The sum of all the projects' percentages of increase in energy security equals nearly $70 \%$. In reality this number would be slightly lower due to the overlap of the effects of different projects. Nonetheless, it is likely that Lithuanian energy security level would advance from the pre-critical condition to the normal security condition. 
Lithuanian energy security. Annual review 2011-2012. Kaunas: Vytautas Magnus University, 2013. - 20 p., illustr.

ISSN 2335-7029

e-ISSN 2335-7045

"Lithuanian Energy Security. Annual Review 2011-2012” presents the problematics of Lithuanian energy security, energy security research methods and methodology that allows determining Lithuanian energy security level. This is an interdisciplinary study that analyses energy security issues and encompasses various scholarly disciplines, such as energy, economics, political science and sociology. The study not only provides an overview of Lithuanian energy security dynamics, but also assesses the potential impact of the main energy projects on the energy security level.

UDK 621.311(474.5)

Editor Agnè Čepinskytė

Proofreader Simona Grušaitė

Layout and Cover Designer Janina Baranavičienè

2013-01-08. Run 100 copies. Issuance by Order No. K13-003

Published by Vytautas Magnus University Press

S. Daukanto g. 27, LT-44249, Kaunas

Internet address: http://www.leidykla.vdu.lt

E-mail: info@leidykla.vdu.lt 